\section{Methicillin-resistant Staphylococcus pseudintermedius: an underestimated risk at pet clinic}

\author{
Staphylococcus pseudintermedius meticilina-resistente: \\ um risco subestimado na clínica de animais de companhia
}

Thérèsse Camille Nascimento Holmström (1) Luria Adib David² (1), Cássia Couto da Motta ${ }^{3}$ (D), Thomas Hebert dos Santos ${ }^{2}$ (D), Irene da Silva Coelho ${ }^{4}$ (D), Shana de Mattos de Oliveira Coelho ${ }^{5}$ (D), Dayanne Araújo de Melo ${ }^{6}$ (D) \& Miliane Moreira Soares de Souza ${ }^{7 *}$ (1)

'Animal Science, MSc, Doctorate. Programa de Pós-graduação em Ciências - PPGCV, Universidade Federal Rural do Rio de Janeiro - UFRRJ, Seropédica, RJ, Brasil

Veterinary, Graduation student. Universidade Federal Rural do Rio de Janeiro - UFRRJ, Seropédica, RJ, Brasil

${ }^{3}$ Veterinary, Dr, Autonomus. Rio de Janeiro, RJ, Brasil

${ }^{4}$ Agronomist, Dr, Professor. Departamento de Microbiologia e Imunologia Veterinária, Instituto de Veterinária, Universidade Federal Rural do Rio de Janeiro - UFRRJ, Seropédica, RJ, Brasil

${ }^{5}$ Biologist, Dr, Professor. Departamento de Microbiologia e Imunologia Veterinária, Instituto de Veterinária, Universidade Federal Rural do Rio de Janeiro - UFRRJ, Seropédica, RJ, Brasil

${ }^{6}$ Veterinary, Dr, Post doctorate. Programa de Pós-graduação em Ciências, Tecnologia e Inovação em Agropecuária - PPGCTIA Universidade Federal Rural do Rio de Janeiro - UFRRJ, Seropédica, RJ, Brasil

`Veterinary, PhD, Professor. Departamento de Microbiologia e Imunologia Veterinária, Instituto de Veterinária, Universidade Federal Rural do Rio de Janeiro - UFRRJ, Seropédica, RJ, Brasil

\section{Abstract}

The prevalence of methicillin-resistant Staphylococcus pseudintermedius (MRSP) as a cause of infectious disease in companion animals remains unknown. The emergence of MRSP is a challenge in veterinary medicine as multidrug-resistant strains began to emerge, resulting in treatment failures. This study provides an overview of the characterization of S. pseudintermedius strains from clinical pet samples and the prevalence of MRSP strains. A total of 123 S. pseudintermedius strains were characterized by phenotypic testing and the MALDI-TOF technique and evaluated for susceptibility to methicillin and the presence of the mecA gene. Of these, 49 (39.8\%) were identified as MRSP. The results confirm the importance of monitoring resistant pathogens and the need for further studies to determine the prevalence of MRSP in companion animals. The prevalence of methicillin-resistant Staphylococcus pseudintermedius (MRSP) as a cause of infectious disease in companion animals remains unknown. This study provides an overview of the characterization of S. pseudintermedius strains from clinical pet samples and the prevalence of MRSP strains. A total of 123 S. pseudintermedius strains were characterized by phenotypic testing and the MALDI-TOF technique and evaluated for susceptibility to methicillin and the presence of the mecA gene. Of these, 49 (39.8\%) were identified as MRSP. The results confirm the importance of monitoring resistant pathogens and the need for further studies to determine the prevalence of MRSP in companion animals. Keywords: Staphylococcus pseudintermedius, methicillin resistance, mecA gene, companion animals.

\section{Resumo}

A prevalência de Staphylococcus pseudintermedius (MRSP) resistente à meticilina como causadores de doenças infecciosas em animais de companhia permanece desconhecida. O surgimento de MRSP é um desafio na medicina veterinária, já que cepas resistentes a múltiplas drogas começaram a surgir, resultando em falhas no tratamento. Este estudo fornece uma visão geral sobre a caracterização de cepas de S. pseudintermedius oriundas de amostras clínicas de animais de companhia e a prevalência de cepas de MRSP. Um total de 123 cepas de S. pseudintermedius foram caracterizados através de provas fenotípicas e pela técnica de MALDI-TOF e avaliadas quanto à suscetibilidade à meticilina e à presença do gene mecA. Destas, 49 (39,8\%) foram identificados como MRSP. Os resultados confirmam a importância do monitoramento de patógenos resistentes e a necessidade de mais estudos para determinar a prevalência de MRSP em animais de companhia.

Palavras-chave: Staphylococcus pseudintermedius, resistência à meticilina, gene mecA, animais de companhia.

\section{BJ M \\ Brazilian Journal of Veterinary Medicine \\ p-ISSN 0100-2430 \\ e-ISSN 2527-2179 \\ ○}

How to cite: Holmström, T. C. N., David, L. A., Motta, C. C., Santos, T. H., Coelho, I. S., Coelho, S. M. O., Melo, D. A., \& Souza, M. M. S. (2020). Methicillin-resistant Staphylococcus pseudintermedius: an underestimated risk at pet clinic. Brazilian Journal of Veterinary Medicine, 42 e107420.

10.29374/2527-2179.bjvm107420

Financial support: The Coordination for the Improvement of Higher Education Personnel (CAPES), Technological Development (CNPq) supported this work and Foundation of Support for Research in the State of Rio de Janeiro (FAPERJ).

Conflict of interests: No conflict of interests declared concerning the publication of this article.

Received: September 05, 2019

Accepted: February 27, 2020.

The study was carried out at Laboratório de Bacteriologia Veterinária, Microbiologia e Imunologia Veterinária, Universidade Federal Rural do Rio de Janeiro - UFRRJ, Seropédica, RJ, Brasil.

\section{*Correspondence}

Miliane Moreira Soares de Souza

Departamento de Microbiologia e Imunologia Veterinária, Universidade Federal Rural do Rio de Janeiro - UFRRJ

Campus Seropédica, Rodovia BR 465, Km 07, s/n Zona Rural

CEP 23890-000 - Seropedica (RJ), Brasil

E-mail:milianemss@gmail.com

Copyright Holmström et al This is an Open Access article distributed under the terms of the Creative Commons Attribution Non-Commercial License which permits unrestricted non-commercial use, distribution, and reproduction in any medium provided the original work is properly cited. 


\section{Introduction}

The antimicrobial-resistant superbugs are an emerging global disease, and one of the three most significant threats to public health in the 21st century (Courvalin, 2016; Holmes et al., 2016). Gram-positive bacterial strains classified as a high priority, level 2, by the World Health Organization include methicillin-resistant Staphylococcus aureus with intermediate resistance or resistance to vancomycin.

The emergence of multiresistant Gram-positive bacterial strains is a serious challenge for small animals medicine. Staphylococcus species distribution and the prevalence of multidrug-resistant strains in clinical specimens are still relatively unknown. Also, the presence and circulation of mecA gene implicated in methicillin resistance at Staphylococcus pseudintermedius population is still a big concern. Besides, S. aureus is no longer considered the only species of clinical importance since the critical review published by Devriese et al. (2005) that highlighted underestimated species such as $S$. pseudintermedius.

This relatively recent classification, based on molecular characteristics, has transfigured the diagnosis of several infections in companion animals. It also emphasized the need for a better understanding of resistance identification and characterization methods in Staphylococcus species, given their impact as a potential reservoir of resistance genes that can be disseminated to other species, including S. aureus (Devriese et al., 2009).

The last decade has been quite prolific in this subject, and LABAC-VET/UFRRJ has had the opportunity to contribute significantly to the advance in the state of the art of this theme (Motta et al., 2014; Melo et al., 2014). The present work aimed to evaluate the occurrence and resistance profile of S. pseudintermedius in clinical samples from infectious processes of companion animals.

\section{Material and methods}

\section{Sampling}

The isolates of S. pseudintermedius studied were obtained from clinical samples sent to Veterinary Microbiological Diagnosis from different infectious processes in dogs and cats. The characterization of $S$. pseudintermedius strains was performed by biochemical tests (Table 1) and by the MALDI-TOF mass spectrometry technique. The present study was submitted to the Animal Experimentation and Use Committee (protocol number: CEUA 1652171215).

Table 1. Results in phenotypic identification of Staphylococcus coagulase-positive species.

\begin{tabular}{cccccccl}
\hline Coagulase & Bacitracina & Polimixina B & VP & Manitol & Manose & Maltose & \multicolumn{2}{c}{ ID } \\
\hline+ & $\mathrm{R}$ & $\mathrm{S}$ & - & $(+)$ & + & $+/-$ & S.pseudintermedius \\
+ & $\mathrm{R}$ & $\mathrm{S}$ & low & $\mathrm{ND}$ & $\mathrm{ND}$ & $-/$ low & S. intermedius \\
+ & $\mathrm{R}$ & $\mathrm{ND}$ & - & + & + & + & S.delphini \\
+ & $\mathrm{R}$ & $\mathrm{R}$ & + & + & + & + & S. aureus \\
+ & $\mathrm{R}$ & $\mathrm{ND}$ & - & - & - & + & S. aureus subsp. anaerobius \\
+ & $\mathrm{R}$ & $\mathrm{ND}$ & + & + & + & - & S. schleiferi subsp.coagulans \\
+ & $\mathrm{R}$ & $\mathrm{R}$ & - & + & + & - & S. hyicus
\end{tabular}

VP: Voges-Proskauer. ND: Not determinated; R: Resistant; S: Suscetible; (+) 11- 89\% of the isolates are positives; ID: Identification.

\section{Isolation and presumptive identification of coagulase-positive Staphylococcus (SCP)}

Clinical samples were submitted to routine phenotypic identification, which consisted of primary isolation on Blood Base Agar (KASVI ${ }^{\circledR}$ ) plus 5\% defibrinated sheep blood. The plates were incubated at $35 \pm 2{ }^{\circ} \mathrm{C}$ for 24 hours. After presumptive identification of the colonies, they were submitted to the Gram staining method to confirm their morphotintorial characteristics and catalase test. Catalase-positive Gram-positive cocci were then picked on Mannitol Salt Agar (microMED, ISOFAR ${ }^{\circledR}$ ) and incubated $35 \pm 2^{\circ} \mathrm{C}$ for 24 hours to obtain cultures of Staphylococcus spp. 
After incubation, the characteristics of the colonies and the fermentation or not of mannitol were observed (Koneman et al., 2008).

\section{Coagulase}

Coagulase detection test was performed using bacterial growth obtained in $1 \mathrm{~mL}$ Brain Heart Infusion broth (HIMEDIA ) incubated at $35 \pm 2{ }^{\circ} \mathrm{C}$ for 24 hours. An aliquot of $200 \mu \mathrm{L}$ of each sample was added to $200 \mu \mathrm{L}$ of rabbit plasma (Larboclin ), followed by incubation at 35 $\pm 2{ }^{\circ} \mathrm{C}$ for 6 hours for clot visualization (Koneman et al., 2008). The strain Staphylococcus aureus subsp. aureus ATCC $25923 \mathrm{TM}$ was used as a control (positive coagulase).

\section{Bacitracin and polymyxin susceptibility test}

A direct suspension of the McFarland 0.5 equivalent colony was distributed over the surface of a Müeller Hinton Agar (KASVI ) Petri plate using a swab. The disk of 0.04 IU bacitracin and $300 \mu$ g polymyxin (Sensifar, Cefar ) were deposited on the medium surface containing the inoculum. After incubation for 24 hours at $35 \pm 2{ }^{\circ} \mathrm{C}$, the zone of inhibition around the disk was observed and measured. Staphylococcus spp. are resistant to bacitracin (Koneman et al., 2008; Markey et al., 2013), and the species Staphylococcus pseudintermedius is susceptible to polymyxin, presenting a halo $\geq 10 \mathrm{~mm}$ (Markey et al., 2013). The strain Staphylococcus aureus subsp. aureus ATCC 25923TM was used as a control (bacitracin and polymyxin resistant).

\section{Voges-Proskauer and fermentation of mannose and maltose}

SCP isolates were identified by Voges-Proskauer (VP), maltose, and mannose fermentation tests (Koneman et al., 2008). The S. pseudintermedius CD93 and Staphylococcus aureus subsp. aureus ATCC 25923TM were used as controls. The Voges-Proskauer test was performed using $1 \mathrm{~mL}$ of MR-VP Broth (Vetec Química Fina ). The use of production of acetoin as a final product of glucose fermentation is indicated by the pink coloration after the addition of $100 \mu \mathrm{L}$ of $5 \% \alpha$-naphthol and $300 \mu \mathrm{L}$ of $\mathrm{KOH}(40 \%)$ in the broth containing the inoculum incubated for 24 hours at $35^{\circ} \mathrm{C} . \pm 2{ }^{\circ} \mathrm{C}$. The fermentation of mannose and maltose sugars was evaluated using base broth containing phenol red $\mathrm{pH}$ indicative (microMED, ISOFAR ) and 1\% sugar. Acid production, indicated by $\mathrm{pH}$ decrease and consequent color change, was evaluated after 24 hours at $35 \pm 2{ }^{\circ} \mathrm{C}$.

\section{Proteomic analysis by MALDI-TOF MS}

Samples were inoculated in BHI agar at $37^{\circ} \mathrm{C}$ for $24 \mathrm{~h}$. Each culture was transferred to a microplate (96 MSP, Bruker - Billerica, USA). Each bacterial sediment was covered by a lysis solution (70\% formic acid; Sigma-Aldrich ). Additionally, a 1- $\mu \mathrm{L}$ aliquot of matrix solution (alpha-ciano-4-hidroxicinamic acid diluted in 50\% acetonitrile and 2.5\% trifluoracetic acid, Sigma-Aldrich ) was added to each sediment. The spectra of each sample were generated in a mass spectrometer (MALDI-TOF LT Microflex, Bruker ) equipped with a $337 \mathrm{~nm}$ nitrogen laser in a linear path, controlled by the FlexControl 3.3 (Bruker ) program. The spectra were collected in a mass range between 2,000-20,000 m/s, and then were analyzed by the MALDI Biotyper 2.0 (Bruker ) program, using the standard configuration for bacteria identification, by which the spectrum of the sample is compared with the references in the database. The results vary on a 0-3 scale, where the highest value means a more precise match and reliable identification.

\section{Phenotypic detection of methicillin-resistance}

Methicillin-resistance detection in Staphylococcus pseudintermedius was performed according to the recommendations of the Clinical Laboratory Standard Institute (2018). The strains were screened by oxacillin disk-diffusion test considering an inhibition zone diameter $\leq 17 \mathrm{~mm}$ as resistantS. pseudintermedius CD93 standard strain were used as control.

\section{Detection of mecA gene by PCR}

A $1.5 \mathrm{~mL}$ overnight culture of a single Staphylococcus colony was centrifuged (three times) and the cell pellet was suspended in $600 \mu \mathrm{L}$ of lysis solution (200 mM TrisHCl, $25 \mathrm{mM}$ EDTA, $25 \mathrm{mM} \mathrm{NaCl}, 1 \% \mathrm{SDS}, \mathrm{pH} 8.0$ ) at $65^{\circ} \mathrm{C}$ for $30 \mathrm{~min}$. The DNA was extracted with Chloroform: Isoamyl 
Alcohol 25:24:1 twice and precipitated by ice-cold ethanol two volumes. DNA pellet was washed with 70\% ethanol and resuspended in $30 \mu \mathrm{L}$ of TE buffer (10 mM Tris-HCl, $1 \mathrm{mM}$ EDTA, pH8.0) and stored at $-20^{\circ} \mathrm{C}$ until used. PCR for mecA gene was initially carried out using the primers and methodology outlined by Murakami et al. (1991): 5'-AAA ATC GAT GGT AAA GGT TGG C-3' and 5'-AGT TCT GCA GTA CCG GAT TTGC-3'. Amplicons were detected by 1.5\% agarose gel, stained with SYBR Green (Invitrogen) and examined under UV transilluminator (UvTrans).

\section{Results}

One hundred and twenty-three strains were characterized as S. pseudintermedius at phenotypic analyses. Most of the samples evaluated were of canine origin (115/123) and the main sources were cutaneous swab (35/123), urine (29/123) and otologic swab (12/123). Most feline samples positive for this pathogen were from infection in urinary tract (7/8).

The MALDI-TOF technique presented results ranging from S. pseudintermedius (38/123), S. intermedius (13/123), S. pseudintermedius/S. intermedius (70/123), Staphylococcus belonging to the SIG group (2/123) (S. intermedius, S. pseudintermedius and S. delphini).

Phenotypic screening of MRSP strains by the oxacillin disk-diffusion test revealed 43.9\% (54/123) of resistant strains. The mecA gene was found in 39.8\% (49/123) isolates, of which 65.3\% (32/49) were phenotypically resistant to methicillin.

\section{Discussion}

Most S. pseudintermedius positive from canine samples were obtained from infectious processes on the skin, ear and urinary tract in agreement with reports that point to these as the main sites of S. pseudintermedius infection (Weese \& Van Duijkeren, 2010; Bannoehr \& Guardabassi, 2012), whereas in cats there was a prevalence of this pathogen in urinary tract infections, this difference may be explained by the fact that infectious processes in the skin and otitis are more frequent in dogs than in cats (Morris et al., 2006). These results corroborate the findings in the literature that point out that the occurrence of S. pseudintermedius in dogs is more frequent (Worthing et al. 2018).

Given the difficulty of discrimination by biochemical identification in routine laboratories, new technologies have been employed to overcome these limitations and thus enable better species differentiation. MALDI-TOF MS mass spectrometry has been introduced in human and animal diagnostic laboratories due to its cost-effectiveness and fast and accurate approach (Bannoehr \& Guardabassi, 2012).

Identification results obtained by the MALDI-TOF technique may vary due to characteristics of the database used for interpretation. A database that aimed primarily at identifying strains from infectious processes in humans may present a misidentification to analyze spectra generated from animal samples, showing different results for SIG group members. Thus, it is important to note that this identification depends on the standardization and regular updating of the database (Guardabassi et al., 2017), especially for the discrimination of members of the SIG group (Decristophoris et al., 2011; Murugaiyan et al., 2014).

Correct identification of the Staphylococcus species involved in the infectious process is crucial for detection of methicillin resistance, once a specific phenotypic marker, oxacillin or cefoxitin should be used depends on the staphylococci species (Clinical Laboratory Standard Institute, 2018). Phenotypic methicillin screening tests including cefoxitin disk diffusion for S. aureus, S. lugdunensis and Coagulase-negative staphylococci, the isolates are resistant if zone diameter $\leq 21 \mathrm{~mm}$ by a mechanism mecA mediated, and to identify methicillin-resistant Staphylococcus pseudintermedius and S. schleiferi is preconized oxacillin disk diffusion, and the isolates are resistant if zone diameter $\leq 17 \mathrm{~mm}$ (resistance mecA mediated) according CLSI. However, phenotypic expression of beta-lactam resistance in Staphylococcus isolates is usually heterogeneous, and the amplification of mecA gene is prescribed as a gold standard method (Clinical Laboratory Standard Institute, 2018).

The results revealed a significant percent of MRSP in the isolates analyzed. The worldwide emergence of MRSP has become one of the main problems for veterinary medicine (Pomba et al., 2017) and the infections caused by this agent, a challenge apart. 
Studies have described that MRSP strains may exhibit resistance to other classes of antimicrobials, resulting in an even greater therapeutic difficulty than the challenge already discovered, beta-lactam resistance (Santos et al., 2016). These findings are of concern because they show the spread of MRSP in companion animals, especially dogs, dramatically reducing the therapeutic options available for treating infections.

\section{Conclusion}

The wide spread of S. pseudintermedius at veterinary clinic requires accurate protocols for its identification, as well as a specific analysis of the resistance profile, since the occurrence of multiresistant MRSP strains dramatically reduces the therapeutic options available for the treatment of these infections.

\section{Acknowledgements}

The Coordination for the Improvement of Higher Education Personnel (CAPE S), Technological Development (CNPq) supported this work and Foundation of Support for Research in the State of Rio de Janeiro (FAPERJ).

\section{References}

Bannoehr, J., \& Guardabassi, L. (2012). Staphylococcus pseudintermedius in the dog: taxonomy, diagnostics, ecology, epidemiology and pathogenicity. Veterinary Dermatology, 23(4), 253-e52. http://dx.doi.org/10.1111/j.13653164.2012.01046.x. PMid:22515504.

Clinical Laboratory Standard Institute - CLSI. (2018). M31-A3: performance standarts for antmicrobial disk and dilution susceptibility tests for bacteria isolated from animals (3rd ed.). Wayne: CLSI.

Courvalin, P. (2016). Why is antibiotic resistance a deadly emerging disease? Clinical Microbiology and Infection, 22(5), 405-407. PMid:26806259.

Decristophoris, P., Fasola, A., Benagli, C., Tonolla, M., \& Petrini, O. (2011). Identification of Staphylococcus intermedius Group by MALDI-TOF MS. Systematic and Applied Microbiology, 34(1), 45-51. PMid:21300509.

Devriese, L. A., Hermans, K., Baele, M., \& Haesebrouck, F. (2009). Staphylococcus pseudintermedius versus Staphylococcus intermedius. Veterinary Microbiology, 133(1-2), 206-207. PMid:18760884.

Devriese, L., Vancanneyt, M., Baele, M., Vaneechoutte, M., De Graef, E., Snauwaert, C., Cleenwerck, I., Dawyndt, P., Swings, J., Decostere, A., \& Haesebrouck, F. (2005). Staphylococcus pseudintermedius sp. nov., a coagulasepositive species from animals. International Journal of Systematic and Evolutionary Microbiology, 55(Pt 4), 1569-1573. PMid:16014483.

Guardabassi, L., Damborg, P., Stamm, I., Kopp, P. A., Broens, E. M., \& Toutain, P.-L. (2017). Diagnostic microbiology in veterinary dermatology: present and future. Veterinary Dermatology, 28(1), 146-e30. PMid:28133869.

Holmes, A. H., Moore, L. S., Sundsfjord, A., Steinbakk, M., Regmi, S., Karkey, A., Guerin, P. J., \& Piddock, L. J. (2016). Understanding the mechanisms and drivers of antimicrobial resistance. Lancet, 387(10014), 176-187. PMid:26603922.

Koneman, E. W., Allen, S. D., Janda, W. M., Schreckenberger, P. C., \& Winn, J. R. (2008). Diagnóstico microbiológico (6. ed.). Rio de Janeiro: MEDS.

Markey, B., Leonard, F., Archambault, M., Cullinane, A., \& Maguire, D. (2013). Clinical veterinary microbiology (2nd ed., pp. 105-119). London: Mosby Elsevier.

Melo, D. A., Coelho, I. S., Motta, C. C., Rojas, A. C., Dubenczuk, F. C., Coelho, SDE. M., \& Souza, M. M. (2014), Impairments of mecA gene detection in bovine Staphylococcus spp. Brazilian Journal of Microbiology, 45(3), 1075-1082. PMid:25477945.

Morris, D. O., Rook, K. A., Shofer, F. S., \& Rankin, S. C. (2006). Screening of Staphylococcus aureus, Staphylococcus intermedius and Staphylococcus schleiferi isolates obtained from small companion animals for antimicrobial resistance: a retrospective review of 749 isolates (2003-04). Veterinary Dermatology, 17(5), 332-337. PMid:16961819.

Motta, C. C., Rojas, A. C. C. M., Dubenczuk, F. C., Botelho, L. A. B., Moreira, B. M., Coelho, S. M. O., Coelho, I. S., \& Souza, M. M. S. (2014). Verification of molecular characterization of coagulase positive Staphylococcus from bovine mastitis with matrix-assisted laser desorption ionization, time-of flight mass spectrometry (MALDI-TOF MS) mass spectrometry. African Journal of Microbiological Research, 8(48), 3861-3866.

Murakami, K., Minamide, W., Wada, K., Nakamura, E., Teraoka, H., \& Watanabe, S. (1991). Identification of methicillin resistant strains of staphylococci by Polymerase Chain Reaction. Journal of Clinical Microbiology, 29(10), 2240-2244. http://dx.doi.org/10.1128/JCM.29.10.2240-2244.1991. PMid:1939577. 
Murugaiyan, J., Walther, B., Stamm, I., Abou-Elnaga, Y., Brueggemann-Schwarze, S., Vincze, S., Wieler, L. H., Lübke-Becker, A., Semmler, T., \& Roesler, U. (2014). Species differentiation within the Staphylococcus intermedius group using a refined MALDI-TOF MS database. Clinical Microbiology and Infection, 20(10), 1007-1015. PMid:24807701.

Pomba, C., Rantala, M., Greko, C., Baptiste, K. E., Catry, B., Van Duijkeren, E., Mateus, A., Moreno, M. A., Pyörälä, S., Ružauskas, M., Sanders, P., Teale, C., Threlfall, E. J., Kunsagi, Z., Torrenedo, J., Jukes, H., \& Törneke, K. (2017). Public Health Risk of Antimicrobial Resistance Transfer from Companion Animals. The Journal of Antimicrobial Chemotherapy, 72(4), 957-968. PMid:27999066.

Santos, T. P., Damborg, P., Moodley, A., \& Guardabassi, L. (2016). Systematic review on global epidemiology of methicillin-resistant staphylococcus pseudintermedius: inference of population structure from multilocus sequence typing data. Frontiers in Microbiology, 7, 1599. PMid:27803691.

Weese, J. S., \& Van Duijkeren, E. (2010). Methicillin-resistant Staphylococcus aureus and Staphylococcus pseudintermedius in veterinary medicine. Veterinary Microbiology, 140(3-4), 418-429. PMid:19246166.

Worthing, K. A., Schwendener, S., Perreten, V., Saputra, S., Coombs, G. W., Pang, S., Davies, M. R., Abraham, S., Trott, D. J., \& Norris, J. M. (2018). Characterization of staphylococcal cassette chromosome mec elements from methicillin-resistant Staphylococcus pseudintermedius infections in Australian animals. MSphere 3(6), e00491-18. http://dx.doi.org/10.1128/mSphere.00491-18. PMid:30404937. 